\title{
The Development of Local Wisdom Based Character Education Training Module
}

\author{
Dionisius Heckie Puspoko Jati ${ }^{*}$, Bambang Ismanto ${ }^{2}$, Bambang S. Sulasmono ${ }^{3}$
}

1,2,3 Master of Education Management, Satya Wacana Christian University

A R T I C L E I N F O

Article history:

Received 01 December

2018

Received in revised

form

31 December 2018

Accepted 15 January

2019

Available online 25

February 2019

Keywords:

development, training

modules, character

education

\section{A B S T R A C T}

The development of local wisdom-based character education training modules is included in $R$ \& $D$ research. This development research uses Sugiyono's development model with the following steps: (1) potential and problems, (2) data collection, (3) product design, (4) design validation, (5) design revision, (6) product testing and (7) product revision. In this study, trials were limited to 10 teachers. Data collection with interviews, questionnaires and validation. Next, the data analysis uses the normality test, hypothesis test, likert scale. The results of the data analysis obtained normal data, in which the hypothesis test concluded that there was a difference between the pretest and posttest training, the questionnaire results showed a value of 3.2 was said to be feasible. Furthermore, the validation test obtained the number $77,5 \%$ in the category worthy of being tested. This module consists of modules for trainers and modules for participants along with plans for implementing training. Principals are advised to carry out training with local wisdom-based character education training modules, for teachers it is recommended to participate in training. 


\section{Introduction}

The morale of the nation's generation is decreasing, this is indicated by the existence of deviant behaviors carried out by young people such as forming motorcycle gangs, getting caught up in promiscuity, using alcoholic beverages and drugs, brawling every year has increased (BPS, 2014: 59) . How to interact with young people with parents, the interaction of students with teachers is now also changing. They pay less attention to manners which are part of character education and local wisdom when interacting (Ruyadi, 2010: 17). This prompted the government and society to try to improve the morale of the nation's generation. One of the efforts is by planting character values through character education and local wisdom in schools to build student character.

The implementation of character education in schools is divided into 3 (three) ways of implementation namely a) integration in subjects, b) through extracurricular activities and c) school culture (Kemendikbud, 2017: 9). Meanwhile, the personality possessed by the teacher also influences the implementation of character education. The mature and strong personality and character of the teacher can be an example and become a source of inspiration for their students. According to Nursyamsi (2014: 1) the quality of psychological relationships between teachers and students will be created if supported by the personality of a good teacher. Teacher's personality and responsibilities are as follows: a) carrying out optimal teaching and learning process, b) having behavior, thoughts, and characteristics of a teacher who can be emulated, c) able to realize his professional performance.

In developing professional competence, there are efforts made by the teacher. One of the efforts to improve teacher competence is character by conducting or participating in training. The implementation of character education training at the Christian Middle School 2 Salatiga was conducted in the Workshop Review and Revision of 2013 Curriculum. In accordance with the following school vision "UNGGUL IN PRIVATE VOCATIONAL SCHOOL OF TECHNOLOGY BASED ON CHRISTIAN FAITH AND MORAL VALUES DEVELOPING IN COMMUNITY", character education training activities need to be held . In this activity, the teacher makes syllabus, prota, promissory notes and rpp by integrating the values of character education in learning. Weaknesses found are guidelines for implementing activities. Difficulties experienced in integrating character values in learning devices according to the 2013 curriculum. The existence of training guidelines will facilitate the process of running the training carried out by the school. According to Bambang and Reza (2016) there is a need for guidance in the implementation of training to help participants understand the material.

The training module is seen as an option for guidance in carrying out training activities. Esti Sumarah's research, et al (2017: 2) states that the training modules used can improve teacher competency, then Sri Giarti's research (2016: 1) shows that training using andragogy-based PTK training modules assisted by Moodle CMS is higher than before using the andragogy-based PTK-based scientific writing training module assisted by Moodle CMS.

The training module contains the application of class-based character education, school culturebased character education and community-based character education (Kemendikbud, 2017: 3). Specifically cultural character education based on the community is closely related to local wisdom. Novia's research (2016) states that the value of local wisdom can foster character. Local wisdom-based character education was also put forward by Wagiran (2012) who argued that the character grew in local wisdom especially in the values of Javanese culture.

Therefore, it is necessary to develop a character education training module that specifically discusses local wisdom. This training module is needed to assist schools in conducting training. Modules are seen as one of the training guide choices that will be made. Based on this, the researchers developed a local wisdom-based character education module.

Character education is a school effort that is designed and implemented systematically to instill the values of student behavior. Character education plays an important role in efforts to improve the quality of human resources. In the era of globalization, character education has a role in fostering national character in order to safeguard national identity, as well as making the Godhead, just and civilized humanity, spirit of Indonesian unity, populist spirit led by wisdom in representative deliberation, and social justice for all the people of Indonesia, it requires commitment and support from state institutions, the business world and industry, the public, the mass media and other stakeholders to develop work programs and coordinate with relevant parties to create a strong synergy to create a better Indonesia (Imam Suyitno, 2017: 2).

Saptono (2011: 23) states that character education is a deliberate effort to develop good character based on core virtues that are objective for both individuals and society. Thomas Lickona (in Gunawan, 2017: 23) argues that character education is education forming personality whose results are seen in a person's real actions which are reflected in good behavior, honesty, responsibility, respect for the rights of 
others, hard work. The same thing in the two opinions above is about the focus on developing an individual's character. These characters are manifested with real behavior in everyday life based on the values that exist in society such as mutual respect, mutual respect, living in harmony, mutual cooperation.

According to Kevin \& Karen (2009: 5), character education is interpreted as follows: "character education is the deliberate effort to help people understand, care about, and act upon core ethical valu es." (Character education is a deliberate effort to help understand human beings , caring and core for ethical/ moral values). In this case Koesoma (2011: 231 further explains that character education is everything that teachers do in the learning process in class with students, which is able to influence the character of students. Teachers help shape the character of students. This includes exemplary how teacher behavior, the way the teacher speaks or delivers material, how the teacher tolerates.

Meanwhile, character education according to David Elkinnd \& Freddy Sweet (in Zubaedi, 2010: 15) "Character education is a deliberate effort to help people understand, care about and act upon ethical value". (Character education is a deliberate effort (realized) to help people understand, care about and practice ethical values.) Character education is everything that teachers do to influence the character of students. The teacher helps in shaping the character of students by giving example, how to speak or convey good material, tolerance, and various other related things (Asmani, 2011: 31).

From the expert's opinion above, it can be concluded that character education is a school effort that is designed and implemented systematically to instill student behavioral values that relate to God, oneself, fellow human beings, an environment that is manifested in daily behavior .

Character education plays an important role in efforts to improve the quality of human resources. In the era of globalization, character education has a role in fostering national character in order to safeguard national identity, as well as making the Godhead, just and civilized humanity, spirit of Indonesian unity, populist spirit led by wisdom in representative deliberation, and social justice for all the people of Indonesia, it requires commitment and support from state institutions, the business world and industry, the community, mass media and other stakeholders to develop work programs and coordinate with relevant parties to create a strong synergy to create a better Indonesia (Rukiyati , 2016: 5). Quality characters need to be formed and nurtured early. There are a number of parties that greatly influence the formation of children's character, such as family, community, friends, school environment, etc. Many experts say that failure to plant characters in someone from an early age will form a problematic person in his adult life.

Character education is important because of the emergence of deviant behaviors carried out by young people, such as forming motorcycle gangs, being caught up in promiscuity, using alcoholic beverages and drugs, each year increasing brawls (BPS, 2014: 59). The way to interact with young people and parents, the interaction of participants in learning with teachers is now also changing. They have paid less attention to manners which are part of character education and local wisdom when interacting (Ruyadi, 2010: 17).

The implementation of character education in schools is divided into 3 (three) forms of activities namely a) integration in subjects, b) through extracurricular activities and c) school culture. Integration in subjects means a series of implementation of teaching and learning processes in mandatory teacher classes to develop student character. The chosen learning method can be a medium for character development (Kemendikbud, 2017: 9). Character Education through extracurricular activities, students can develop their character. By practicing working together, independence and responsibility as an extracurricular participant. Furthermore, Character Education builds a good school culture can be done through activities at school. (Ministry of Education and Culture, 2017: 24).

Neng Gustini (2016) stated that local wisdom is a local (local) culture or ideas that are wise, full of wisdom, and of value that are embedded and followed by members of the community. Furthermore, Pratama Bayu (2017) said that local wisdom is manifested in ideas, behaviors and activities carried out by the community in responding to their various needs. Local wisdom-based education has an important role and meaning in people's lives.

The component of this local wisdom-based character education training module consists of; the first part, 1) the introduction contains a general explanation of the importance of character education and local wisdom in schools that requires teachers to improve competence by attending character education training and learning indicators; 2) learning activities consist of three materials, namely character education in schools, local wisdom and training scenarios, summaries, competency tests, answer keys; 3 ) bibliography. 


\section{Methods}

This development according to Sugiyono (2015: 409) consists of 10 steps, namely: (1) potential and problems, (2) data collection, (3) product design, (4) design validation, (5) design revisions, (6) trials products, (7) product revisions, (8) usage trials, (9) product revisions and (10) mass production. However, in this study only to step 7, due to consideration of the time and facilities needed to conduct research on the development of this module.

The study was conducted at Salatiga 2 Christian Middle School with 10 school principals and teachers. Implementation of research from October 2018 to January 2019.

This training module was developed with the ADDIE model. The ADDIE model used is explained as follows: (1) Analysis, the researcher analyzes the needs of the training module. (2) Design or draft a training module draft. (3) Development, develop training modules consisting of modules for trainers and modules for trainees. (4) Implementation is carried out through limited testing in Salatiga 2 Christian Middle School. (5) Evaluation, the researcher conducted a revision of the local wisdom-based character education training module developed based on the input obtained from the response questionnaire.

Data analysis used descriptive percentage techniques and categorical to describe the feasibility of the module. At first the score of the results of the assessment using a closed questionnaire is summed then the score is scored. Based on the percentage categories obtained, the results of the validation test for the development of training modules can be said to be feasible to be tested if the average percentage rate reaches a high category $(>61 \%)$.

The data collected is done using test and non-test techniques. The test is used to measure the competency of the training results. Meanwhile, non-test techniques for measuring the quality of training modules. Data analysis on test techniques using quantitative descriptive analysis techniques and different tests. Different test techniques of competency averages the results of the training were carried out by non-parametric test techniques by Whiteney by calculating the difference in the average results of the pretest and posttest. Quantitative descriptive analysis and different tests were carried out with the help of SPSS 20.00 for Windows. Previously researchers tested the normality first (with a P value> 0.05, the distribution is normal and vice versa if $\mathrm{P}<0.05$, the distribution is not normal)

Furthermore, the Independent Sample T-test was used to determine whether there were differences in pretest and posttest. The testing criteria based on the significance of the T-test are as follows:

Ho is accepted if the significance is $>0.05$

Ho is rejected if the significance is $<0.05$

The instruments in this study for questionnaires use a Likert scale with four variations of answers.

Table 1. Likert scale

\begin{tabular}{clc}
\hline No & Category & Skor \\
\hline 1 & Strongly agree / very good & 4 \\
2 & Agree / good & 3 \\
3 & Less agree / less good & 2 \\
4 & Disagree / not good & 1 \\
\hline
\end{tabular}

The scores obtained are then converted into four module feasibility categories according to Djemari Mardapi (2008: 123) which are displayed in the following table:

Table 2. Module feasibility categories

\begin{tabular}{cc}
\hline Skor & Category \\
\hline 4 & Very good / very decent \\
3 & Good / decent \\
2 & Fairly good enough \\
1 & Poor / inadequate \\
\hline
\end{tabular}

Modules are declared feasible if the results of the study for the average feasibility test have at least the criteria "Fairly Worthy". 


\section{Result and Discussion}

This research uses research and development methods. The local wisdom-based character education training module is the final result of the research. This research uses Sugiyono's research design by taking up to the 7 th step.

a. Potential and Problems

Preliminary study in this research and development, as described in Chapter III was conducted by interview. Interviews were conducted using interview sheets for principals, vice principals, teachers and community leaders. The results of the interviews indicate the potential that 1) the implementation of character education in schools through integration in subjects, 2) through extracurricular activities and 3) school culture, 4) training modules on character education developed previously by the Ministry of Education and Culture.

Furthermore, the problem faced is the difficulty of teachers in integrating character education in the eye through the implementation of learning plans (RPP). The existence of a character education training module developed previously by the Ministry of Education and Culture has not been enough to help teachers in integrating character values. The importance of modules or guidelines for implementing training is needed by teachers in conducting training. Because the teacher has difficulty in making plans for implementing learning. Difficulties and problems experienced in integrating character values in learning devices according to the 2013 curriculum. The phenomenon of the ineffectiveness of the training modules conducted is still dependent on the trainer. This situation has an impact on the results of the planned implementation of learning that is not appropriate.

b. Data collection

The researcher conducted a literature review of several reading sources and relevant research regarding character education, training modules and local wisdom in schools in order to make local wisdom-based character education training modules. Literature search by the author on the training modules developed so far found that there are actually character education training modules published by the Ministry of Education and Culture. However, this module has weaknesses that are not specifically in the development of material for the implementation of learning in particular the integration of character values. In addition, in the data collection researchers conducted interviews with resource persons who mastered the field of character education and local wisdom

c. Product Design

The product design developed in this study is with local wisdom-based character education training modules. The local wisdom-based character education training module consists of modules for trainers and modules for participants and is complemented by plans for implementing training. This training module was developed with the ADDIE model. The ADDIE model that will be used in this study is explained in detail as follows:

The first step is Analysis, the analysis phase is the stage where the researcher examines the needs of local wisdom-based character education training modules. This need is known through interviews with school principals, vice principals and teachers at Christian Middle School 2 Salatiga. In addition, researchers also conduct studies on relevant research. Results

The study found that teachers need local wisdom-based character education training modules to facilitate the training process and for more effective training. At this stage it can also be said as a potential stage and problem and data collection.

Next is the Design stage, the second stage of the ADDIE model is the design or design stage. The design referred to as the draft training module. The local wisdom-based character education training module consists of training modules for trainers, training modules for participants and supplemented with training implementation plans. This stage is the product design stage.

Development (Development), the development stage is the stage of product realization. At this stage the development of training modules was carried out in accordance with the design. After that, it will be validated by material expert lecturers, module expert lecturers and practitioner teachers at the school. In the validation process, the validator uses instruments that have been prepared in the previous stage. The purpose of product training module validation is to know the strengths and weaknesses of the training modules conceptually by material experts and module experts and practically by practitioners in the school. Data from the validation test results were analyzed by descriptive percentage techniques and categorical to describe the feasibility of the module.

Implementation (Implementation) is carried out limitedly to schools designated as research sites. The selected school is Salatiga 2 Christian Middle School which includes 10 teachers. Data collection techniques using test and non-test techniques. The test technique is used to measure the competency of the training results. Meanwhile, non-test techniques for measuring the quality of training modules. Data 
analysis on test techniques using quantitative descriptive analysis techniques and different tests. Different test techniques with the results of the Indonesian pretest and posttest. Quantitative descriptive analysis and different tests were carried out with the help of SPSS 20.00 for Windows. Before carrying out data analysis, a normality and gain score test is done first. Next is to determine the hypothesis as follows:

Ho: teacher competence after carrying out training with local wisdom-based character education training modules is lower or equal to before using local wisdom-based character education training modules.

Ha: teacher competence after conducting training with local wisdom-based character education training modules is higher with before using local wisdom-based character education training modules.

Evaluation (Evaluation) at this stage, the researcher conducted the final revision of the local wisdom-based character education training module which was developed based on the input obtained from the response questionnaire. This is so that the developed local wisdom-based character education training module is truly suitable and can be used by wider schools. At this stage it is called product revision.

d. Design Validation

The design of the local wisdom-based character education training module has been validated by (1) Dr. Mawardi, M.Pd as an expert in character education materials, (2) Dr. Yari Dwikurnaningsih, M.Pd as module expert and (3) Marmini Estiningsih, S.Pd., M.Pd as prospective users at the school. The validation test results from the validator obtained a percentage of $77,5 \%$ including the high category and said to be feasible to be tested.

e. Design revision

After discussion with the validator, weaknesses and various suggestions for product improvement were obtained. Revisions are carried out by researchers based on the results of validation with the experts concerned. Revisions made in the following sections: 1) The learning objectives are replaced as training objectives, this is because this module is a training module, it is not appropriate to write down the learning objectives, 2) Learning objectives that originally only emphasized the knowledge aspect added skills aspects, 3) Formulation of competencies added in the module, 4) The plan for conducting the training is reviewed regarding the composition and contents, 5) Questions in the competency test are added to the question of the Higher Order Thingking Skill (HOTS), 6) In the module added media (pictures, tables and diagrams) for mastery of the material, 7) Addition of material and examples of local wisdom that are more specific to a particular area, 8) The use of grammar in the module is considered especially the adjustment to the Indonesian spelling.

f. Product testing

The test technique is used to measure the competency of the training results. Meanwhile, non-test techniques for measuring the quality of training modules. Data analysis on test techniques using quantitative descriptive analysis techniques and different tests. Different competency test techniques on the results of the training were conducted using the Independent Sample T-test technique by calculating the difference in the average results of the pretest and posttest. Quantitative descriptive analysis and different tests were carried out with the help of SPSS 20.00 for Windows. Before conducting data analysis, the test is first carried out normality.

Based on the output of the data normality analysis above, it can be seen that the significance value for the pretest of the experimental class is 0.096 and the control class pretest is 0.158 . Because the significance for all classes of variables $>0.05$, it can be concluded that the population of pretest and posttest data is normally distributed.

Based on the output of the $t$ test (Independent Sample T-test) it can be known Sig. (2-tailed) $<0.05$, which is $0.025<0.05$ means Ho, namely teacher competency after conducting training with lower local wisdom based character education training modules or the same as before using the local wisdom-based character education training module was rejected and Ha, namely the competence of teachers after conducting training with higher local wisdom-based character education training modules by using local wisdom-based character education training modules was accepted. So it can be concluded that there are differences in pretest and posttest training.

Furthermore, the comments written by the participants are that the module is useful to make it easier to learn local wisdom-based character education and the images displayed are adapted to the material to make it more interesting. Participants are interested in the module, because both are used by the teacher in planning learning but still need improvement. Based on the average results obtained from ten participants, the local wisdom-based character education training module was declared good / feasible with an average value of 3.2 .

g. Product revision

After limited testing with the training participants, weaknesses and various suggestions for product improvement were obtained. The revision was carried out by researchers based on the results of the 
questionnaire filled out by the training participants. The researcher adds images that are in accordance with the material so that participants can understand the material presented in the module. The revision will produce a local wisdom-based character education training module that is ready to be tested.

The discussion of the development of this training module refers to the formulation of the problem described in Chapter I, which is about how to develop a local wisdom-based character education training module. Development of local wisdom-based character education training modules through 7 steps, namely: (1) potential and problems, (2) data collection, (3) product design, (4) design validation, (5) design revision, (6) product testing, (7) product revisions.

The first step, finding potential and problems more effectively guides the writer in mapping the problems faced by the principal and the teacher in the school. In this step successfully helping the author determine the topics or topics that are the headings of each part of the training module developed.

Furthermore, the author's data collection step analyzes the training modules developed so far to find that there are actually character education training modules issued by the Ministry of Education and Culture. However, this module has weaknesses that are not specifically in the development of material for the implementation of learning in particular the integration of character values.

The product design developed in this study is with local wisdom-based character education training modules. The local wisdom-based character education training module consists of modules for trainers and modules for participants and is complemented by plans for implementing training.

Furthermore, the design of local wisdom-based character education training modules has been validated by (1) Dr. Mawardi, M.Pd as an expert in character education materials, (2) Dr. Yari Dwikurnaningsih, M.Pd as module expert and (3) Marmini Estiningsih, S.Pd., M.Pd as prospective users at the school. Based on the three validators, a percentage of $77,5 \%$ is included in the high category and is said to be feasible to be tested.

After discussion with the validator, weaknesses and various suggestions for product improvement were obtained. Revisions are carried out by researchers based on the results of validation with the experts concerned.

In product trials, test techniques are used to measure the competency of the training results and non-test techniques to measure the quality of the training module. Data analysis on test techniques using quantitative descriptive analysis techniques and different tests. Based on the output of the test (Independent Sample T-test) can be known Sig. (2-tailed) $<0.05$, which is $0.025<0.05$ means that Ho is rejected and Ha is accepted. So it can be concluded that there are differences in pretest and posttest training. Meanwhile, the non-test technique was obtained from the results of the local wisdom-based character education training module declared good / decent with an average value of 3.2.

After limited testing with the training participants, weaknesses and various suggestions for product improvement were obtained. The revision was carried out by researchers based on the results of the questionnaire filled out by the training participants. The researcher added images that were in accordance with the participants' material can understand the material presented in the module. The revision will produce a local wisdom-based character education training module that is ready to be tested.

The development of this training module uses the ADDIE model. The effectiveness in each step of module development is in line with the views of Branch (2009: 1) and Atwi Suparman (2012:108) saying that the ADDIE model has the advantage of being system-oriented, well-known among education practitioners, the steps are simple because the procedure is systematic ie at each step always refer to the previous steps that have been corrected so that an effective product is obtained.

Furthermore, the results of expert validation will be explained which assesses the products of local wisdom-based character education training modules include: (1) Dr. Mawardi, M.Pd as an expert in character education materials, (2) Dr. Yari Dwikurnaningsih, M.Pd as module expert and (3) Marmini Estiningsih, S.Pd., M.Pd as prospective users at the school.

The findings of the average percentage of expert assessment scores on local wisdom-based character education training modules were obtained at a rate of $77,5 \%$. Based on the category and expert validation test, this percentage figure indicates that the assessment results are in the high category. So, local wisdom-based character education training modules are said to be worthy of being tested.

Character education experts who provide RPP advice need to be reviewed, especially with regard to the formulation of training objectives that emphasize knowledge competencies and why the terminology of learning objectives is not the purpose of training. The result of the percentage of module experts is $82.9 \%$. This means that it falls into the very high category.

Module experts provide input that needs to be equipped with media: images, charts, diagrams, and photographs to facilitate mastery of the material. Formulation of objectives and evaluation questions needs to be made Higher Order Thingking Skill (HOTS). There needs to be a competency formula. The lesson plan includes: competency, goals, indicators, participatory training methods not seen in lesson 
plans, incomplete. The results of the percentage of module experts obtained a value of $73.5 \%$. This means it is included in the high category.

Furthermore, practitioners or prospective users in the school provide a critique of the use of Javanese script on the cover is not appropriate, there are special advantages for writing Javanese script. The use of capital letters in the section "Instructions for Using the Module" is incorrect (not in accordance with the Indonesian Spelling General Guidelines). Examples of local wisdom need to be added, for example with fairy tales or local folk tales, folk songs, etc. Need to be sharpened about which local wisdom is meant. The results of the percentage of module experts are $76.3 \%$. This means it is included in the high category.

The role of product validation by these experts is to see whether the product is developed or not. Next, product testing is carried out. With the results, Ho is rejected and Ha is accepted. So it can be concluded that there are differences in pretest and posttest training. The local wisdom-based character education training module seems to have changed. According to Budiyono, Rubiyati, Agus (2014) states that creative training modules can improve teacher competency.

Based on the description of the trial discussion above, teacher competency after using the training module is higher than before using the training module. This conclusion shows the features of this training module compared to previously developed modules.

\section{Conclusion}

Based on the discussion of the results of the research presented in Chapter IV, conclusions are in accordance with the formulation of the research problem. The development of local wisdom-based character education training modules is carried out with the following steps: (1) potential and problems, (2) data collection, (3) product design, (4) design validation, (5) design revisions, (6) product testing, (7) product revision. The findings of the average percentage of expert assessment scores on local wisdombased character education training modules were obtained at a rate of 77, 5\%. Based on the category and expert validation test, this percentage figure indicates that the assessment results are in the high category. This conclusion is based on the results of the validation of character education material experts, module experts and prospective users in the school.

Based on the conclusion of the results of the research and development of the local wisdom-based character education training module above, the suggestions that can be submitted are:

a. For principals, it is recommended to carry out training with local wisdom-based character education training modules, because (1) local wisdom-based character education training modules are provided by teachers in planning learning, (2) developed module designs have been validated by experts, (3) the design of the training module has been tested on a limited basis with reasonable results to be widely tested.

b. For teachers it is recommended to participate the training in accordance with the needs of the field of science, so they can develop their competencies.

c. For researchers who are interested in research and development training modules, the results of this study can be used as reference material in conducting further research by continuing at the extensive trial stage, in different regions, different levels and conducting needs analysis using tests...

\section{References}

Asmani, Jamal Ma'mur. 2011. Buku Panduan Internalisasi Pendidikan Karakter di Sekolah. Yogyakarta: DIVA Press.

Atwi Suparman. 2012. Desain Instruksional Modern. Jakarta: Erlangga

Badan Pusat Statistik. 2014. Statistik Kriminal. Jakarta: Badan Pusat.

Bambang Ismanto dan Reza Pahlevi. 2016. Evaluasi Program Diklat Kompetensi Guru SMK di Balai Pengembangan Pendidikan Kejuruan Jawa Tengah. MMP. UKSW.

Branch Robert maribe. 2009. Instructional Design: The ADDIE Approach. New York : Springer Science \& Business Media, LLC. 2009.

Budiyono Herman, Rubiati, Agus Setyonegoro. 2014. Pengembangan Bahan Pelatihan Desain Sistem Pembelajaran Bagi Guru Bahasa Indonesia SMA. Tekno-Pedagogi Vol. 4 (1), 7-14. 
Esti Sumarah. 2017. Pengembangan Modul Pelatihan Model Pembelajaran Van Hiele Dalam Konteks Pendidikan Karakter Untuk Guru SD. Jurnal Penelitian, Vol. 21, No. 1, Mei 2017 hlm. 38-47.

Gunawan, Heri. 2017. Pendidikan Karakter ( Konsep dan Implementasi). Bandung : Alfabeta.

Kemendikbud. 2017. Modul Pelatihan Penguatan Pendidikan Karakter. Jakarta: Kemendikbud.

Kevin, R \& Karen, E. 2009. Buinding Character in Schools. United State : Jossey Bass.

Koesoemo. 2011. Pendidikan Karakter di Zaman Keblinger (Mengembangkan diri sebagai pelaku perubahan dan pendidik karakter). Jakarta : PT Grasindo.

Imam Suyitno. 2017. Pengembangan Pendidikan Karakter dan Budaya bangsa Berwawasan kearifan lokal. UNM. Researchgate, 11 Maret 2017.

Neng Gustini, dkk. 2016. Cultivating Character education based on Sundanese cultural wisdom.

Novia Fitri Istiawati. 2016. Pendidikan karakter Berbasis Nilai-nilai Kearifan lokal Adat AMMATOA dalam menumbuhkan karakter konservasi. Cendekia, Vol. 10, No.1, April 2016 hlm 1-18.

Nursyamsi. 2014. Pengembangan Kepribadian Guru. Jurnal Al-Ta ' lim, Volume 21, Nomor 1 Februari 2014, hlm. 32-41.

Pratama Bayu, dkk. 2017. Identifyng local in elementary school ati corruption Education in Malang. RJOAS.

Rukiyati. 2016. Model Pendidikan Karakter Berbasis Kearifan lokal pada sekolah Dasar Bantul. Jurnal Pendidikan Karakter UNY, Vol. VI, No.1, April 2016.

Ruyadi, Y. 2010. Model Pendidikan Karakter Berbasis Kearifan Budaya Lokal (Penelitian Terhadap Masyarakat Adat Kampung Benda Kerep Cirebon Provinsi Jawa Barat Untuk Pengembangan Pendidikan Karakter Di Sekolah). Proceedings of The 4th International Conference on Teacher Education; Join Conference UPI \& UPSI Bandung, Indonesia.

Saptono. 2011. Dimensi-dimensi Pendidikan Karakter (Wawasan, Strategi dan langkah Praktis). Erlangga.

Sri Giarti. 2016. Pengembangan Modul Pelatihan Karya Tulis ilmiah Hasil PTK Berbasis Andragogi Berbantuan CMS moodle. Naskah Publikasi Tesis MMP UKSW.

Sugiyono. 2015. Metode Penelitian Pendidikan (Pendekatan Kuantitatif, Kualitatif dan R \& D). Bandung : Alfabeta.

Wagiran, dkk. 2010. Pengembangan Model Pendidikan Kearifan Lokal di Wilayah Provinsi DIY dalam Mendukung Perwujudan Visi Pembangunan DIY menuju Tahun 2025 (Tahun Kedua). Penelitian. Yogyakarta: Biro Administrasi Pembangunan.

Zubaedi. 2013. Desain Pendidikan Karakter, Konsepsi dan Aplikasinya.Jakarta : Kencana Prenada Media Group. 